\title{
High School Students' Common Errors in Writing Essays
}

\author{
Pham Vu Phi Ho ${ }^{1} \&$ Do Thi Phuong Trinh ${ }^{2}$ \\ ${ }^{1}$ BaRia VungTau University, Vung Tau City, Vietnam \\ ${ }^{2}$ Tra Vinh University, Tra Vinh City, Vietnam \\ Correspondence: Pham Vu Phi Ho, BaRia VungTau University, Vung Tau City, Vietnam. Tel: (+84) 909850699; \\ E-mail: hopvp@bvu.edu.vn
}

Received: September 3, 2019 Accepted: September 25, 2019 Online Published: October 28, 2019

doi:10.5539/ijel.v9n6p309 URL: https://doi.org/10.5539/ijel.v9n6p309

\begin{abstract}
Students' writing problems have become one of the first and foremost issues in writing classrooms, and to know the common errors which frequently occur on students' writing papers is usually what the writing teachers have conducted in the classrooms. However, no research study has been conducted at Huynh Man Dat High school to investigate this aspect. The purpose of the current study is to investigate the common written errors on students' writing essays and their attitudes towards the writing process approach. The target subjects are from grade twelve, Huynh Man Dat (HMD) High School. Data collection was from writing tasks and questionnaires. The study found that the four most common errors frequently occur in students' writing journals are relating to tenses, collocations, spellings, and verb forms. The findings from an attitude questionnaire indicated that the students expressed positive attitudes towards it and showed a high appreciation for the effects of process writing.
\end{abstract}

Keywords: common errors, writing approach, writing fluency, writing accuracy

\section{Introduction}

English is considered as an international language. It is the first and foremost criteria when someone is applying for a job or he is seeking admission in a reputed college, university, or institution. However, many students at high school find it difficult to improve their writing skills after they have learned English for years. Emmons (2003) indicates that writing is one of the basic skills that all EFL learners need to be mastered. Writing skill involves composing, which means having the ability to tell or retell pieces of information in the form of narratives or description, and transforming information into new texts, as in expository or argumentative writing. In other words, Omaggio. Nunan (1999) says that the most difficult task to do in language learning is to produce a coherent, fluent, and extended piece of writing, which is even more challenging for foreign language learners. Pham and Pham (2015) investigate the common errors that usually occur on students' writing papers and the effects of extensive writing on enhancing students' writing fluency. The data showed that the four most common errors which frequently occur are tenses, collocations, spellings, and verb forms. In addition, the current study indicates that extensive writing practices help students write smoothly in terms of length of writing. In terms of writing errors, Pham and Usaha (2016) found that student writers could clarify and revise by themselves. They needed reviewers to provide feedback on macro issues.

Ho (2006) investigated how effective process writing is in helping about 200 students at the upper primary school level and the lower primary school level improves their writing skills and their attitudes towards writing. Six primary school teachers, three in the lower primary school level and three in the upper primary school level, each implemented an innovative two-month process writing program in their schools. In 1999, Storch investigates the impact of collaboration on grammatical accuracy across three different tasks: a cloze exercise, a text reconstruction task, and a composition task. The students who worked in group sand had an opportunity to discuss their grammatical choices took longer to complete the tasks but produced more accurate written texts than those working alone. Their compositions were shorter and less syntactically complicated, but overall more accurate.

Al Fadda (2012) found out that the main challenges ESL students encounter are recognizing the difference between written and spoken words and phrases, avoiding grammar errors including subject-verb agreement and combining sentences to make a coherent paragraph. He also indicates that one of the basics of academic writing is learners' ability to get access to the relevant references and evaluate them in order to join different thoughts 
and opinions together so that they can express their own ideas. Haiwen Mo (2013) investigated the current situation of college English writing teaching in China thoroughly, and he found that college students' writing ability is far from satisfactory. Nofal (2010) conducted a study in which he investigated and scrutinized the reasons behind the weaknesses of English major students at Philadelphia University—Jordan. He states that it is difficult for students to express themselves adequately in writing. The most discrete characteristics of a good paragraph are virtually absent in the writing of most students.

Hyland (2008) concludes that to carry out writing tasks, students are searching for solutions to a wide range of problems. Nanun (1989) thinks that at the sentence level the control of content, format, sentence structure, vocabulary, punctuation, spelling and letter formation is what learners of English worry. Moreover, it is important to have the ability to collect others' ideas and write them in his/her own words (Dehkordi \& Allami, 2012). According to Al-Khasawneh and Maher (2010), making an outline, summarizing and paraphrasing are the important points without which students might struggle when writing their tasks. Other basic elements are forming, developing, and organizing ideas (Amin \& Alamin, 2012).

Furthermore, to have a piece of writing without errors, learners should carefully consider how to form a thesis statement, to write convincing supporting sentences, and finally edit them (Alsamdani, 2010). Finally, Al Fadda (2012) claims that learners have to be used to punctuation marks such as the period, comma, semicolon, colon, dash, a hyphen, and capitalization. Besides the sentence level, the writer must be able to structure and integrate information into cohesive and coherent paragraphs and texts." In the history of language teaching, there have been numerous studies that investigate the writing problems which hinder students from introducing a mistake-free piece of writing. Teh (2005) points out that writing is the skill most Malaysian students are less proficient in and they do not know how to accomplish the written tasks in satisfactory ways. Razı (2013) states that Turkish students who learn English as a foreign language usually find it difficult to write in. Unity, consistency, order, and coherence are obviously lacking; students fail to signal the direction of their thoughts by the use of transitional words such as, 'however', 'moreover', 'nevertheless', and phrases like 'on the other hard', 'in fact', 'of course', etc." Al-Buainain (2008) elaborates that there is a consensus among English language instructors at the University of Qatar that most EFL students are weak in writing courses.

Since the early 1990s, due to the impact of English as a global language, the teaching of English in Vietnam has slanted towards the view that places the learner at a focal point with the teacher seen in the role of a facilitator who provides creative contexts for language learning. With this new philosophy of foreign language teaching, the two sets of textbooks that had been in use in Vietnamese general education for nearly two decades had proved to be inadequate. In face of this situation, the Vietnamese Government issued Decree N ${ }^{\circ}$ 14/2001 TC-Tig on the Renovation of the Vietnamese General Education Curriculum, specifying the requirements and the tasks of the Ministry of Education and the concerned ministries and governmental organs. In implementing the Government's Decree, at the beginning of 2002, the Vietnamese Ministry of Education and Training (MOET) organized the design of the new curriculum and the writing of new textbooks for all school subjects. This national project finished in early 2008 when the new textbooks of all school subjects were put into use across the whole general educational system of Vietnam; and in the case of English teaching, we now have one set of English textbooks for lower secondary schools and two sets of English textbooks for upper secondary schools to be used across the country. To promote the study of English further and to better the quality of English teaching and learning in Vietnam to meet the increasing trends of globalization and international interdependency of the global village, on September 30th, 2008 the Vietnamese Prime Minister issued Decision N ${ }^{\circ}$ 1400/QD-TTg on Approving the 10-year National Plan for "Teaching and Learning Foreign Languages in the National Formal Educational System in the Period of 2008-2020".

Recently, several students at Huynh Man Dat high school, in Kien Giang province have to deal with lots of problems when learning English, especially with writing skills. The first reason is the use of the new textbook, which is designed for the 10-year foreign language curriculum by the MOET. In the new textbook, students are expected to write the essay, which is different from the writing tasks in traditional textbooks. Time-limited for a writing lesson is 45 minutes every two weeks. Therefore, many of them don't have enough time to finish their essays, regardless of writing a good essay. In other words, they can't create good writing as expected in the new curriculum. The second reason is that they have the habit of imitating the model text to write their essays, which makes them not creative and their writing skills are not improved. The fact is that after many years of studying English at school with these textbooks, Vietnamese students cannot apply their linguistic ability to real-life situations (Pham \& Nguyen, 2014). As a result, many EFL teachers at Huynh man Dat High School, Kien Giang province, are faced with lots of challenges especially with writing instruction in EFL classrooms to conduct the writing lessons successfully. In other word, the teachers need to use different writing techniques such as creative 
writing, reflective essays, and critical essays and so on in classrooms for students to develop good writing skills. The current study aims to respond to the following research questions.

\section{Research Questions}

1) What are the common writing errors do the students frequently committed to?

2) What attitudes do high school students have about the writing process?

\section{Methodology}

\subsection{Research Context/Population}

There were nearly 1000 students at Huynh Man Dat high school, including three grades (10 classes at grade 10, 10 classes at grade 11 and 11classes at grade 12). More than 300 students were admitted to the school after passing an entrance examination each year. The teaching staff consisted of 90 teachers. ELT group was among the eight teaching groups of our school with 10 members and a group leader. Each grade in HMD high school had two classes specialized in English, using the three-level English language set of textbooks for the Vietnamese upper secondary school. It followed the systematic, cyclical and theme-based curriculum approved by the Ministry of Education and Training in November 2012. The aims of this set of textbooks was to develop students' listening, speaking, reading and writing skills and improve their English language knowledge with a focus on communicative competence so that when they finish upper secondary school, their English would be at level three of the Foreign Language Proficiency Framework for Viet Nam (equivalent to B1 in the Common European Framework of Reference for Languages. The rest were specialized in other subjects such as Mathematics, Physics, Literature, and so on. These classes use traditional textbooks (Tieng Anh 10,11, 12). All of the classes used the textbooks chosen by the Ministry of Education and Training in Viet Nam. The main method used in our school is CLT. Sometimes, The Grammar Translation method was used to teach grammar in the language part. Some modern facilities, such as TVs and laptops were available in all classrooms to support teaching.

Two classes were chosen with 60 students of the two English classes among 330 students at grade 12 from a high school in Kien Giang who were chosen to participate in this study, including 40 females and 20 males. The two classes were at the same level of English and had been learning English for 10 years.

There are five writing lessons with five different topics in Semester 2. I have one writing lesson every two weeks. Each lesson lasts 45 minutes. The first writing lesson is about the topic of Endangered animals. The students are expected to write a report about an endangered species. The second lesson is about Intelligent machines. Students write about the advantages and disadvantages of intelligent machines. The next lesson is about Employment. Students will write a CV to support an application for employment. The fourth lesson is about Jobs. Students write a job application letter in response to an advertisement. The last lesson is Lifelong learning. Students have to write a description of a bar chart about barriers to lifelong learning. Following is the framework of the study.

Table 1. The framework of the study

\begin{tabular}{llll}
\hline Writing process (experimental group) & \multicolumn{2}{l}{ Writing product (control group) } \\
\hline - & Focus on the process & - & Focus on products \\
- & Text as a resource for comparison & - & imitate model text \\
- & ideas as a starting point & - & organization of ideas is more important than ideas themselves \\
- & emphasis on the creative process & - & emphasis on end products \\
- & collaborative & - & individual \\
- & more than one draft & - & one draft \\
\hline
\end{tabular}

\subsection{Questionnaire}

The Likert rating scale was employed in the questionnaire to measure students' degree of response in the investigated areas mentioned above. Though there are several ways to scale responses to questions, the Likert scale is one of the most popular types. This scale, like many others, measures attitudes to set statements put by the questionnaire. The respondent is provided with a scale of possible responses (usually five) to the questionranging from the attitude measure 'strongly agree' to the exact opposite measure of 'strongly disagree' (Birmingham \& Wilkinson, 2003). It is one of the rating scales in which degrees of response, the intensity of the response and the move away from dichotomous questions and rankings have been managed. According to Cohen (2018), these rating scales are useful for the researchers because of the fact that they build in a degree of 
sensitivity and differentiation of response while still generating numbers. Similarly, Manion and Morrison (2000, p. 253) stated "rating scales combine the opportunity for a flexible response with the ability to determine frequencies, correlations and other forms of quantitative analysis."

In this study, there are 20 items in the questionnaire to investigate students' attitude towards process writing during writing lessons. A questionnaire adopted from Belinda (2006), including 20 questions is given out to both groups. It includes two sections: students' bio-data (section 1), learners' attitudes towards the process writing approach to improve their writing performance (section 2). This questionnaire contains closed questions. The questionnaire required the participants to mark the items on five-point Likert scales from 1 (strongly agree), 2 (disagree), 3 (Neutral), 4 (agree), 5 (strongly agree). After that, the data were collected and the questionnaire was reported as valid. Eventually, the information was analyzed, the findings were discussed and supported by literature, and some recommendations were suggested.

\section{Data Collection and Analysis}

The researcher used pre-test, post-test, and questionnaire to collect data. The data were collected in accordance with the two stages of the experimental teaching: (i) students' performance before and after the application of the process approach was explored through the administration of the pre- and post-tests, and (ii) their reflections on the approach were revealed via questionnaires. The results of the pre-test were collected during the second week, while the post-test results are analyzed during week 14. First, the researcher counted the words of every essay to know the length of their writing. Second, common errors were seen as most frequent errors appeared in the students' writing. In addition, scoring rubrics (Table 1) are used to measure students' writing accuracy. A rubric is a scoring tool used to evaluate students' writing performance, which is adapted by EFL Teaching group at Huynh Man Dat High School. Quantitative analysis using a t-test to compare the writing performance of the experimental group. T-test was employed to determine whether there was a statistically significant difference in achievement for the experimental group before and after the use of the writing process.

After the post-test has been completed, participants were asked to answer an attitudes questionnaire which consists of a Likert-type five-point scale rating system adopted from Phisutthangkoon (2012). The questionnaire (see Appendix D) was written in English and explained in Vietnamese so that students had the same understanding of each question on the questionnaire. Students spent about twenty minutes to complete the questionnaire. All students completed the questionnaire.

Relating to research question 1 about the common writing errors that the High school students frequently committed, the researchers use a coding scheme for error analysis adapted from Pham (2015). The purpose of the study was to find the common errors in the real context which students often had in their writing expression. They could help the researcher discover the "real writing errors" in the "real world". This could help the researcher understand the nature of the students in writing skills. Each writing paper was analyzed for errors and the errors recorded. The researcher analyzed common errors in their writing to find the most frequent errors appearing in the students' writing. This analysis was time-consuming. Nine common errors were addressed in this study: verb tenses, verb forms, prepositions, articles, word forms, and adjective-noun orders.

The errors in the students' writing were analyzed as the following examples of the coding scheme in Table 2 as follows. 
Table 2. The coding scheme for error analysis

\begin{tabular}{|c|c|c|c|}
\hline Categories & Definitions & Examples of errors & Corrections \\
\hline Verb Tenses & $\begin{array}{l}\text { The relationship between the form of the verb } \\
\text { and the time of the action or state it describes } \\
\text { (Richards \& Schmidt, 2010). }\end{array}$ & $\begin{array}{l}\text { I studied English for } 6 \text { years. } \\
\text { We didn't meet since we went to } \\
\text { HCM city. }\end{array}$ & $\begin{array}{l}\text { I have studied English for } 6 \text { years. } \\
\text { We haven't met since we went to HCM } \\
\text { city. }\end{array}$ \\
\hline Verb forms & $\begin{array}{l}\text { An English verb can be inflected in five forms: } \\
\text { base form, infinitive form, past form, -ing } \\
\text { participle and -ed participle, which divided into } \\
\text { two categories: semantic and syntactic (Lee \& } \\
\text { Seneff, 2008). }\end{array}$ & $\begin{array}{l}\text { I want buy a laptop. } \\
\text { We must to do a lot of homework. }\end{array}$ & $\begin{array}{l}\text { I want to buy a laptop. } \\
\text { We must do a lot of homework }\end{array}$ \\
\hline Word forms & Word forms refer to part of speech. & $\begin{array}{l}\text { I'm so worry. } \\
\text { Today was a bored day. }\end{array}$ & $\begin{array}{l}\text { I'm so worried. } \\
\text { Today was a boring day. }\end{array}$ \\
\hline Prepositions & $\begin{array}{l}\text { A preposition is a type of a word or group of } \\
\text { words often placed before nouns, pronouns, or } \\
\text { gerunds to link them grammatically to other } \\
\text { words. }\end{array}$ & $\begin{array}{l}\text { When I listen music, I feel } \\
\text { interested. } \\
\text { Nothing can escape his eyes. }\end{array}$ & $\begin{array}{l}\text { When I listen to music, I feel interested. } \\
\text { Nothing can escape from his eyes. }\end{array}$ \\
\hline Articles & $\begin{array}{l}\text { A word which is used with a noun, and which } \\
\text { shows whether the noun refers to something } \\
\text { definite or something indefinite. For example, } \\
\text { English has two articles: the definite article the, } \\
\text { and the indefinite article a or an (Richards \& } \\
\text { Schmidt, 2010). }\end{array}$ & $\begin{array}{l}\text { Today I and my sister went to } \\
\text { Supermarket. } \\
\text { Accident happened to me last week. } \\
\text { I started to cry when the plane } \\
\text { flied. }\end{array}$ & $\begin{array}{l}\text { Today I and my sister went to the } \\
\text { supermarket. } \\
\text { An accident happened to me last week. } \\
\text { I started to cry when the plane took off. }\end{array}$ \\
\hline $\begin{array}{l}\text { Orders of } \\
\text { Adjective and } \\
\text { noun }\end{array}$ & $\begin{array}{l}\text { In English adjectives almost always go before } \\
\text { nouns. }\end{array}$ & $\begin{array}{l}\text { The traffic in Viet Nam has many } \\
\text { problems serious. } \\
\text { People should have solutions } \\
\text { suitable. }\end{array}$ & $\begin{array}{l}\text { The traffic in Viet Nam has many } \\
\text { serious problems. } \\
\text { People should have suitable solutions. }\end{array}$ \\
\hline
\end{tabular}

Relating to research question 2 about students' attitudes do high school students have about the writing process? An attitude questionnaire with 20 items which consisted of a Likert-type five-point scale rating system adopted from Phisuttangkoon (2012) was used to answer this question. The researcher used SPSS 22.0 to run descriptive statistics including Frequency (F) Percentages (P) Mean (M) and Standard Deviation (SD) of each questionnaire item. The data were analyzed based on five-point Likert scale of the agreement levels (Brown, 2010). In order to conveniently get the average value for each of the items in the questionnaire, each of the five choices is designated a value (namely, strongly agree $=1$, agree $=2$, uncertain $=3$, disagree $=4$, and strongly disagree $=5$ ).

\section{Results/Findings and Discussion}

The results of the study were presented under each research question. There were 120 writing papers collected and evaluated in this study. In particular, the control class had 60 papers, including 30 of pre-tests and 30 of post-tests. The mean scores of the 30 pre-test papers had an average of 170 words per paper $(\mathrm{M}=170.2 ; \mathrm{SD}=$ $17.35)$; and the 30 post-test writing papers of the control class had an average of 173 words per essay $(\mathrm{M}=172.5$; $\mathrm{SD}=15.08)$.

Besides, the experimental group had 60 papers, including 30 writing pre-test papers with 171 words per essay (M $=358.71 ; \mathrm{SD}=73.48)$ and 30 writing post-test papers with an average of 195 words per essay $(\mathrm{M}=194.50 ; \mathrm{SD}$ $=15.35)$. The results of the writing papers are shown as below.

Question 1: What are the common writing errors do the students frequently committed to?

In order to respond to this research question, 60 students' written papers in the pre-test were collected for data analyses. Six common errors were addressed in this study: verb tenses, verb forms, collocations, word forms, prepositions, and adjectives and noun order. SPSS version 22. software was run and Frequencies were run to measure Mean, Std. Deviation and Sum of error items.

Table 3. Descriptive statistics

\begin{tabular}{|c|c|c|c|c|c|c|c|}
\hline & & word form & collocations & verb tense & Spelling & Verb form & noun and Adjective order \\
\hline \multirow[t]{2}{*}{$\bar{N}$} & Valid & 60 & 60 & 60 & 60 & 60 & 60 \\
\hline & Missing & 0 & 0 & 0 & 0 & 0 & 0 \\
\hline \multicolumn{2}{|c|}{ Mean } & 3.600 & 5.73 & 6.15 & 4.53 & 4.12 & 3.62 \\
\hline \multicolumn{2}{|c|}{ Std. Deviation } & 1.7094 & 4.250 & 4.632 & 2.646 & 2.894 & 2.775 \\
\hline \multicolumn{2}{|c|}{ Sum } & 216.0 & 344 & 369 & 272 & 247 & 217 \\
\hline
\end{tabular}


The analyses indicate that all the participants committed to most of the errors investigated, and the four most common errors were reported in this study. Tenses were found to be the most common error $(\mathrm{M}=6.1, \mathrm{SD}=4.6)$ in students' writing essays. In Vietnamese, there is no change in word form to indicate a period of time. People tend to use adverb of time which is enough to express what they want. Therefore, when the students wrote in English, they tended to translate their ideas into English.

The second highest number of errors made was of collocations, with a total of 344 errors. Each student committed to about 6 errors of this type $(\mathrm{M}=5.7, \mathrm{SD}=4.2)$. The students might use a bilingual dictionary to use the vocabulary or they did not learn/know the collocations. Most cases of lexical transfer in Vietnamese EFL writing are concerned with collocation errors or phrases. Therefore, special attention should be paid to the collocation differences between the two languages in order to reduce the occurrence of transfer phenomena.

Spelling errors were the third highest error type that the students committed to in this study, with a total of 272 errors of which each student involved in 23 errors in their journals $(\mathrm{M}=4.5, \mathrm{SD}=2.6)$. Spelling is regarded as the third most challenging of Vietnamese students. Students commit spelling errors easily due to the inconsistence between speaking and writing the words in English.

Verb form errors, with 247 errors, were the fourth most error that the students committed to in this study. Each student made 4 mistakes on this type of errors $(\mathrm{M}=4.12, \mathrm{SD}=2.1)$. This type of error might be the cause of so many different rules in the English language compared to the Vietnamese language.

The results of this study bolster most of the previous research studies. According to Wang and Wen (2002), L2 writers obviously get stuck when writing in the target language because their mother tongue mainly affects the use of the second language; as a result, they may at times combine the systems of the two languages in their L2 writing, which is called "language transfer or syntactic transfer". Bhela (1999) also found that the errors caused by the L1 were apostrophe, punctuation, spellings, and Prepositions. Darus and Ching (2009) found that the four most errors that the students frequently committed to were mechanics, tenses, prepositions, and subject-verb agreement and also confirmed the influences of L1 on students' L2 writing. In addition, El-Sayed (1982) revealed that the students participated in his study committed to errors mostly to verbs, pronouns, articles and prepositions and adjectives. Belhhaj (1997) found most errors that the students committed to were tenses, adjectives, prepositions, and articles. Sattayatham and Honsa (2007) confirmed that the most frequent errors the students frequently committed to were at syntactic and lexical levels which led to the overgeneralization, incomplete rule application, and building of false sentences. Watcharapunyawong and Usaha (2013) found that the students frequently committed to tenses, word choice, sentence structure, article, and preposition.

Most of the previous studies found errors in prepositions were the third or fourth most frequent errors while it was in the fifth most errors in this study and in Watcharapunyawong and Usaha (2013)'s also. Surprisingly, the order of adjectives and nouns was the least frequent errors in the current study $(\mathrm{M}=1.6 ; \mathrm{D}=0.3)$ when the Vietnamese language (mother tongue) has different orders, mostly nouns first, then adjectives. In English, this order was seen the opposite. The findings of the current study set lights for the teachers of English, who wished to know the most common errors of the students to show or train them in the blackboard (as they usually do) for the frequent errors as samples to help students avoid these mistakes in their writing practice every day. This indication comes from Ferris (2004)'s suggestion that before providing comments on students' papers, it is crucial for a writing teacher to be aware of error categories frequently found in his/her students'. Data analysis from this question revealed six common errors were addressed in this study: verb tenses, verb forms, collocations, word forms, prepositions, and adjective and noun order. However, the authors of the current study did not imply for error corrections on these areas in the peer response activities because Trustcott (1996) argues that for both theoretical and practical reasons, comments on errors can expect it to be ineffective and it has harmful effects. In addition, Semke (1984) states that student progress is enhanced by writing practice alone. Corrections do not increase writing accuracy, writing fluency, or general language proficiency, and they may have a negative effect on student attitudes, especially when students must make corrections by themselves.

The results of this study bolster many of previous research studies, such as Pham and Pham (2015), Wang and Wen (2002), Darus and Ching (2009), Belhhaj (1997), and El-Sayed (1982). As Pham and Pham (2015) stated, the four most common errors frequently occur in students' writing journals are relating to tenses, collocations, spellings, and verb forms. According to Wang and Wen (2002), EFL students obviously get stuck when writing in the target language because their mother tongue mainly affects the use of the second language; as a result, they may frequently combine the systems of the two languages in their L2 writing, which is called "language transfer or syntactic transfer." Bhela (1999) also found that the errors caused by the L1 were apostrophe, punctuation, spellings, and prepositions. Darus and Ching (2009) found that the four most errors that the students 
at times committed to were mechanics, tenses, prepositions, and subject-verb agreement and also confirmed the influences of the first language on students' writing. In addition, El-Sayed (1982) revealed that the students participated in his study committed to errors mostly to verbs, pronouns, articles and prepositions and adjectives. Similarly, Belhhaj (1997) found most errors that the students committed to were tenses, adjectives, prepositions, and articles. Sattayatham and Honsa (2007) confirmed that the most frequent errors the students committed to were at syntactic and lexical levels which led to the overgeneralization, incomplete rule application, and building of false sentences. Watcharapunyawong and Usaha (2013) found that the students frequently committed to tenses, word choice, sentence structure, article, and preposition.

Question 2: -What attitudes do high school students have about the writing process?

As for the third question of the study, the means and standard deviation were measured for all items included in the attitude questionnaire to know exactly how students felt about using the process writing approach to enhance their EFL writing skills. The following table showed the results obtained from distributing the attitude questionnaire to the students.

Table 4. Cronbach's alpha-questionnaire reliability

Reliability statistics

\begin{tabular}{lll}
\hline Cronbach's Alpha & Cronbach's Alpha based on Standardized Items & N of Items \\
\hline .946 & .944 & 20 \\
\hline
\end{tabular}

As can be seen from Table 4, the Cronbach's alpha is .946 , providing an overall reliability coefficient for a set of 20 questions, which suggested that the questionnaire was sufficiently reliable.

The results were also analyzed based on the mean (M) and standard deviation (S.D.). If the mean score of an item of the questionnaire ranges from 1 to 2.6, it can be concluded that the participants don't agree with the idea of that item in the questionnaire. Then, if the mean score is from 2.61 to 3.4, the researcher can confirm that the students neither agree nor disagree with the idea of that item. Finally, when the mean score is from 3.41 to 5.0, there is a likelihood that students agree with the idea they were asked to check.

Table 5. Data of Questionnaire analysis

\begin{tabular}{llll}
\hline Content & $\mathrm{N}$ & Mean & Std. Deviation \\
\hline Item 1. Brainstorming has effects on developing ideas. & 30 & 3.70 & .915 \\
Item 2. Brainstorming is helpful for getting the idea to write. & 30 & 4.20 & 1.186 \\
Item 3. Brainstorming encourages effective writing. & 30 & 3.90 & 1.398 \\
Item 4. Drafting helps reduce errors. & 30 & 4.13 & .819 \\
Item 5. Working with peers is motivated. & 30 & 3.60 & .894 \\
Item 6. Collaborative work is effective. & 30 & 3.67 & .711 \\
Item 7. Collaborative activities are interesting. & 30 & 3.63 & .850 \\
Item 8. Peer feedback helps improve my writing fluency. & 30 & 4.63 & .490 \\
Item 9. Peer feedback in writing process helps me reduce my writing errors. & 30 & 3.43 & .935 \\
Item 10. Peer feedback should be encouraged during writing lesson. & 30 & 3.80 & 1.349 \\
Item 11. Peer response promotes students' autonomy. & 30 & 3.43 & .935 \\
Item 12. Peer response helps students feel more confident. & 30 & 3.70 & .651 \\
Item 13. Working with peers is relaxing. & 30 & 3.63 & .669 \\
Item 14. It is easier to write after revising. & 30 & 3.70 & .535 \\
Item 15. Revising makes my writing accuracy better. & 30 & 4.23 & .430 \\
Item 16. Revising improves my writing fluency & 30 & 3.43 & 1.006 \\
Item 17. Teacher's feedback is important during the lesson. & 30 & 3.57 & .679 \\
Item 18. Teacher's feedback is necessary at the end of the writing lesson. & 30 & 2.77 & .971 \\
Item 19. Teacher's feedback is not as important as peer feedback. & 30 & 2.10 & .305 \\
Item 20. One draft is not enough to have a good essay. & 30 & 3.43 & .858 \\
\hline
\end{tabular}

As can be seen from Table 5, item 1 (Brainstorming has effects on developing ideas), item 2 (Brainstorming is helpful for getting the idea to write) and item 3 (Brainstorming encourages effective writing) gained the mean of acceptance from 3.7 to 4.2 . Such the above results highlighted the close relationship between the process writing approach and brainstorming as students had more freedom to brainstorm new ideas through working together within one group. Item 4 (drafting helps reduce errors) with the third rank of the mean score $(M=4.13)$ indicated the significance of drafting in students' writing. In addition, item 5 (working with peers is helpful), 
item 6 (collaborative work is effective), and item 7 (collaborative activities are interesting) had the mean scores over 3.6. Especially, item 8 (peer feedback helps improve my writing accuracy) came first with the mean score 4.6. Item $9(\mathrm{M}=3.43$ - peer feedback in writing process helps me reduce my writing errors), item $10(\mathrm{M}=3.8$ peer feedback should be encouraged during a writing lesson), and item $11(\mathrm{M}=3.43$ - peer response promotes students' autonomy). Item 12 ( $\mathrm{M}=3.70$ - working with peers helps students feel more confident) and item 13 $(\mathrm{M}=3.63$ - Working with peers is relaxing). The data also revealed that peer response and working with peers in the writing process were effective. Item 14. $(\mathrm{M}=3.70$ - It is easier to write after revising), item $15(\mathrm{M}=4.23$ Revising makes my writing accuracy better), and item $16(\mathrm{M}=3.43$ - Revising improves my writing fluency emphasized the effectiveness of revising on students' writing).

The mean score of item $17(\mathrm{M}=3.57)$ Teacher's feedback is important during the lesson) confirmed the indispensable role of the teacher. Teacher feedback could help students improve both grammar and fluency (Pham \& Nguyen, 2019). Therefore, item 18 (Teacher's feedback is necessary at the end of the writing lesson) and item 19 (Teacher's feedback is not as important as peer feedback) came last in the order of acceptance as the mean of its acceptance reached 2.77 and 2.1. It could be inferred from the result that Teacher's feedback was important during the lesson. In other words, it played as the same important role as peer feedback to help students improve their writing performance in terms of accuracy and fluency. Finally, item 20 (One draft is not enough to have a good essay) had the mean 3.4, which showed the effectiveness of drafting in the writing process. In conclusion, the above results showed that the participants in the current study agreed on the items included in the attitude questionnaire.

The data from the attitude questionnaire revealed that the participants in the current study agreed on the items included in the attitude questionnaire. Firstly, the data analysis shows that students highly appreciated the process approach for its effectiveness in their writing performance. Specifically, the steps during the experimental teaching, i.e., brainstorming, peer feedback, revising, and teachers' feedback offered students a lot of benefits in their own writing.

\section{Conclusion}

The study shows the most frequent types of errors the students made in their writing. The results of the study help clarify the students' difficulties in writing for the teachers. The length of their writing papers improved after the treatment of process writing. In other words, the process writing approach helps students write better and more fluently in expressing ideas. Making errors is inevitable in the language learning process. Clarifying errors keeps the teachers informed on what aspects need further attention in the training process. To solve this kind of problem, Pham (2019) suggested a model for training students to become effective peer reviewers to help one another improve their writing quality.

In addition, the results of this study highlight certain issues regarding teaching and learning writing in English as a second/foreign language. Teachers/educators in similar situations may utilize those results to enhance the teaching and learning of L2 writing. Firstly, language interference should be taken into consideration during writing classes as the use of L1 which might affect writing performance in L2. Teacher/peer feedback should be applied during the writing activities to help students learn from each other to enhance writing quality. Teachers should offer students opportunities for a sufficient amount of writing practice.

The findings of the study have yielded similar results as in the study of Ho (2006). The results attitude questionnaire of this study revealed that students were very positive in their attitudes towards writing after the implementation of process writing.

\section{References}

Abdulkareem, M. N. (2013). An Investigation Study of Academic Writing Problems Faced by Arab Postgraduate Students at Universiti Teknologi Malaysia (UTM). Theory \& Practice in Language Studies, 3(9). https://doi.org/10.4304/tpls.3.9.1552-1557

Abu, G. A. (1998). Teaching English as a foreign language: Procedures, techniques and activities. Tawbah Library, Riyadh.

Ahmed, S. A., \& Alamin, A. (2012). Skills and strategies used in the comprehension and production of academic writing in Taif University. English Language and Literature Studies, 2(3), 134. https://doi.org/10.5539/ells.v2n3p134

Al-Buainain, H. (2011). Students' Writing Errors in EFL: A Case Study. QNRS Repository, 1, 2601.

Al Fadda, H. (2012). Difficulties in academic writing: From the perspective of King Saud University 
postgraduate students. English Language Teaching, 5(3), 123. https://doi.org/10.5539/elt.v5n3p123

Al-Khasawneh, F. M. (2010). Writing for Academic Purposes: Problems faced by Arab postgraduate students.

Al Murshidi, G. (2014). UAE university male students' interests impact on reading and writing performance and improvement. English Language Teaching, 7(9), 57. https://doi.org/10.5539/elt.v7n9p57

Alsamadani, H. A. (2010). The relationship between Saudi EFL students' writing competence, L1 writing proficiency, and self-regulation. European Journal of Social Sciences, 16(1), 53-63.

Ansari, A. A. (2012). Teaching of English to Arab students: Problems and remedies. Educational Research, 3(6), $519-524$.

Arndt, V. (1987). Six writers in search of texts: A protocol-based study of L1 and L2 writing. ELT Journal, 41(4), 257-267. https://doi.org/10.1093/elt/41.4.257

Badger, R., \& White, G. (2000). Product, process and genre: Approaches to writing EAP. ELT Journal, 54(2), 153-160. https://doi.org/10.1093/elt/54.2.153

Belhaj, A. M. (1997). Contrastive Textual Analysis: An Arabic-English English-Arabic Translation Corpus. Occasional Papers, 24(25), 103-150.

Brown, D. (2001). Teaching by principles: An interactive approach to language pedagogy. White Plains, Addison: Welsey Longman.

Cohen, L., Manion, L., \& Morrison, K. (2002). Research methods in education. Routledge. https://doi.org/10.4324/9780203224342

Darus, S., \& Ching, K. H. (2009). Common errors in written English essays of form one Chinese students: A case study. European Journal of Social Sciences, 10(2), 242-253.

Dehkordi, M. E., \& Allami, H. (2012). Evidentiality in academic writing. Theory and Practice in Language Studies, 2(9), 1895. https://doi.org/10.4304/tpls.2.9.1895-1904

Ellis, R. (1985). Teacher-pupil interaction in second language development. Input in Second Language Acquisition, 69-85. https://doi.org/10.2307/328357

El-Sayed, A. M. (1982). An Investigation into the Syntactic Errors of Saudi Freshmen's English Compositions. Unpublished Ph. D. Dissertation: Indiana University of Pennsylvania, U.S.A.

Ferris, D. R. (2004). Treatment of Error in Second language Student Writing. Michigan: The University of Michigan Press.

Geen, S. K., \& Gredler, M. E. (2002). A review and analysis of constructivism for school-based practices. Review, 31(1), 53-70.

Graham, S., \& Sandmel, K. (2011). The process writing approach: A meta-analysis. The Journal of Educational Research, 104(6), 396-407. https://doi.org/10.1080/00220671.2010.488703

Grami, G. M. A. (2010). The effects of integrating peer feedback into university-level ESL writing curriculum: A comparative study in a Saudi context.

Hein, G. (1991). Constructivist learning theory. Institute for Inquiry. Retrieved from https://www.exploratorium.edu/education/ifi/constructivist-learning

Henderson, L. (1982). Orthography and word recognition in reading. Academic Press.

Ho, B. (2006). Effectiveness of using the process approach to teach writing in six Hong Kong primary classrooms. Perspectives: Working papers in English and Communication, 17(1), 1-52.

Hoang, V., Hoang, T. X. H., Dao, N. L., Vu, T. L., Do, T. M., \& Nguyen, Q. T. (2011). Tieng Anh 12 (English textbook for class 12).

Hyland, K. (2008). Writing theories and writing pedagogies. Indonesian JELT, 4(2), 1-20.

Kagan, S., \& Kagan, S. (1994). Cooperative learning (Vol. 2). San Juan Capistrano, CA: Kagan Cooperative Learning.

Khaldieh, S. A. (2000). Learning strategies and writing processes of proficient vs. less - proficient1 learners of Arabic. Foreign Language Annals, 33(5), 522-533. https://doi.org/10.1111/j.1944-9720.2000.tb01996.x

Maarof, N., \& Murat, M. (2013). Writing strategies used by ESL upper secondary school students. International Education Studies, 6(4), 47-55. https://doi.org/10.5539/ies.v6n4p47 
Mo, H. (2012). A study of the teaching of ESL writing in colleges in China. International Journal of English Linguistics, 2(1), 118. https://doi.org/10.5539/ijel.v2n1p118

Myles, J. (2002). Second language writing and research: The writing process and error analysis in student texts. Tesl-Ej, 6(2), 1-20.

Nofal, K. (2011). The Reasons Behind the English Major Students' Weaknesses in Philadelphia University. Damascus University Journal, 27(1), 2.

Nunan, D. (1999). Second language teaching and learning. Boston: Heinle \& Heinle.

Ortega, L. (2009). Studying writing across EFL contexts: Looking back and moving forward. Writing in Foreign Language Contexts: Learning, Teaching, and Research, 232-255. https://doi.org/10.21832/9781847691859-013

Pham, V. P. H. (2019). The Effects of Lecturer's Model e-comments on Graduate Students' Peer e-comments and Writing Revision. Computer Assisted Language Learning, Published online: 09 Jul 2019, Taylor \& Francis production. https://doi.org/10.1080/09588221.2019.1609521

Pham, V. P. H., \& Nguyen, T. B. (2014). The Effects of Communicative Grammar Teaching on Students' Achievement of Grammatical Knowledge and Oral Production. English Language Teaching, 7(6), 74-86. https://doi.org/10.5539/elt.v7n6p74

Pham, V. P. H., \& Nguyen, T. T. H. (2019). The Effects of Peer-video Recording on students' Speaking Performance. International Journal of English Linguistics, 9(4), 178-191. https://doi.org/10.5539/ijel.v9n4p178

Pham, V. P. H., \& Pham, N. T. D. (2015). Common Errors in Writing Journals of the English-Major Students at HCMC Open University. Journal of Science Ho Chi Minh City Open University, 2(14).

Pham, V. P. H., \& Usaha, S. (2016). Blog-based peer response for L2 writing revision. Computer Assisted Language Learning, 29(4), 724-748. https://doi.org/10.1080/09588221.2015.1026355

Razi, O., \& Grenfell, M. J. (2012). The impact of linguistic knowledge on learner strategy deployment. Procedia-Social and Behavioral Sciences, 47, 818-822. https://doi.org/10.1016/j.sbspro.2012.06.741

Reid, J. M. (1993). Teaching ESL writing. New Jersey: Prentice Hall Regents.

Sattayatham, A., \& Honsa, S. (2007). Medical students' most frequent errors at Mahidol University, Thailand. The Asian EFL Journal, 9(2), 170-194.

Semke, H. D. (1984). Effects of the red pen. Foreign Language Annals, 17(3), 195-202. https://doi.org/10.1111/j.1944-9720.1984.tb01727.x

Smalley, R. L., Ruetten, M. K., \& Kozyrev J. R. (2001). Refining composition skills: Rhetoric and grammar. Boston: Heinle \& Heinle.

Steele, V. (2004). Product and process writing: a comparison. Retrieved March 23, 2014.

Tahaineh, Y. S. (2010). Arab EFL university students' errors in the use of prepositions. Modern Journal of Applied Linguistics, 1(6), 76-112.

Tribble, C. (1996). Writing. Oxford: Oxford University Press.

Truscott, J. (1996). The case against grammar correction in L2 writing classes. Language Learning, 46(2), 327369. https://doi.org/10.1111/j.1467-1770.1996.tb01238.x

Ur, P. (2012). A course in English language teaching. Cambridge University Press.

Watcharapunyawong, S., \& Usaha, S. (2013). Thai EFL Students' Writing Errors in Different Text Types: The Interference of the First Language. English Language Teaching, 6(1), 67-78. https://doi.org/10.5539/elt.v6n1p67

Weigle, S. C. (2002). Assessing Writing. Cambridge: Cambridge University Press. https://doi.org/10.1017/CBO9780511732997

Wenyu, L., \& Yang, L. (2008). Research on EFL writing strategy using SRP: An empirical study in DUT. The Asian EFL Journal, 10(2), 51-83.

Wingate, U. (2012). Using academic literacies and genre-based models for academic writing instruction: A 'literacy' journey. Journal of English for Academic Purposes, 11(1), 26-37. https://doi.org/10.1016/j.jeap.2011.11.006 
Wolfe, E. W., Song, T., \& Jiao, H. (2016). Features of difficult-to-score essays. Assessing Writing, 27, 1-10. https://doi.org/10.1016/j.asw.2015.06.002

Vygotsky, L. (1978). Interaction between learning and development. Readings on the Development of Children, 23(3), 34-41.

\section{Copyrights}

Copyright for this article is retained by the author, with first publication rights granted to the journal.

This is an open-access article distributed under the terms and conditions of the Creative Commons Attribution license (http://creativecommons.org/licenses/by/4.0/). 